MEDIA ILMIAH TEKNIK SIPIL

\title{
STUDI ALTERNATIF PERANCANGAN SUBSTRUCTURE PADA JEMBATAN DESA KUALA TAMBANGAN
}

\section{ALTERNATIVE STUDY OF SUBSTRUCTURE DESIGN ON KUALA TAMBANGAN VILLAGE BRIDGE}

\author{
Eka Purnamasari ${ }^{1}$, Revian Daffa Sosiawan ${ }^{2}$ \\ 1,2 Program Studi Teknik Sipil, Fakultas Teknik, Universitas Islam Kalimantan MAB Banjarmasin \\ Korespondensi: eka.ftsuniska@gmail.com
}

\begin{abstract}
ABSTRAK
Abutmen adalah bangunan bawah jembatan yang terletak pada kedua penyangga ujung pilar jembatan, berfungsi sebagai pemikul beban yang terjadi pada struktur atas jembatan termasuk beban angin beban plat lantai atau gaya yang terjadi oleh beban vertikal kebawah. Wilayah Provinsi Kalimantan Selatan akan melakukan pelebaran jalan yaitu pada ruas Batakan Desa Kuala Tambangan Kabupaten Tanah Laut. Maka dibangunlah jembatan pada Desa Kuala Tambangan berlokasi di Ruas Batakan yang diharapkan akan menunjang transportasi. Panjang bentang jembatan tersebut yaitu $25,00 \mathrm{~m}$ dan memiliki lebar $6,00 \mathrm{~m}$. Analisis yang dilakukan yaitu merencanakan alternatif struktur bangunan bawah pada jembatan Desa Kuala Tambangan . Pembebanan menggunakan LRFD (Load and Resistance Factor Design), standard pembebanan untuk jembatan SNI 1725:2016 dan RSNI T-12-2004 (perencanaan struktur beton untuk jembatan). Bedasarkan hasil perhitungan Substructure Abutment jembatan memiliki panjang sebesar 8,00 m, dan lebar sebesar 2,80 m. Mutu beton yang digunakan yaitu $25 \mathrm{MPa}$ dan mutu baja tulangan yaitu BJ-TD 35 dengan mutu baja $343 \mathrm{MPa}$.
\end{abstract}

Kata Kunci: substructure, abutmen, perancangan, jembatan

\begin{abstract}
Abutmen is an under-bridge building located at both ends of the bridge pillars, serving as a load bearer that occurs on the upper structure of the bridge including the wind load load of the floor plate or force that occurs by the vertical load down. The province of South Kalimantan will widen the road, namely on the Batakan section of Kuala Tambangan Village, Tanah Laut Regency. Therefore, a bridge was built in Kuala Tambangan Village located in Batakan Section which is expected to support transportation. The length of the bridge span is $25.00 \mathrm{~m}$ and has a width of $6.00 \mathrm{~m}$. The analysis was to plan an alternative structure of the lower building on the Kuala Tambangan Village bridge. Loading using LRFD (Load and Resistance Factor Design), loading standard for SNI 1725:2016 bridge and RSNI T-12-2004 (concrete structure planning for bridge). Based on the calculation of Substructure Abutment bridge has a length of $8.00 \mathrm{~m}$, and a width of $2.80 \mathrm{~m}$. The quality of concrete used is $25 \mathrm{MPa}$ and the quality of reinforcing steel is BJ-TD 35 with a steel quality of $343 \mathrm{Mpa}$.
\end{abstract}

Keywords: substructure, abutment, design, bridge 


\section{PENDAHULUAN}

Seiring meningkatnya perkembangan suatu daerah yang mengikuti arus perkembangan zaman, maka setiap aspek taraf hidup dan juga perekonomian dengan sendirinya harus di tingkatkan. Untuk itu jembatan yang merupakan prasarana perhubungan mempunyai fungsi yang sangat penting untuk menunjang perkembangan dan peningakatan transportasi di daerah-daerah, baik itu perhubungan darat maupun perhubungan laut.

Untuk itu perlu adanya gagasan-gagasan dari pemerintah untuk membangun jembatan di suatu daerah guna mempermudah setiap akses bagi daerah tersebut. Dengan lancarnya sarana perhubungan pada suatu daerah akan berdampak pada pesatnya pertumbuhan perekonomian daerah tersebut, karena mobilisasi barang dan jasa dapat berjalan lancer dan efisien serta berguna juga untuk membuka daerah-daerah yang terisolir sekaligus dalam pengembangan wilayah.

Di wilayah Provinsi Kalimantan Selatan akan dilakukan pelebaran jalan di Ruas Batakan. Di daerah tersebut akan di bangun Jembatan yang akan menunjang transportasi di daerah tersebut salah satunya adalah pembangunan jembatan Desa Kuala Tambangan pada Ruas Batakan. Pembangunan jembatan serta pembangunan jalan di daerah tersebut akan sangat mempengaruhi lancarnya akses kegiatan dan transportasi di daerah tersebut dan juga dapat meningkatkan potensi ekonomi serta kesejahteraan masyarakat di daerah tersebut.

Sejak dikeluarkannnya standar pembebanan untuk jembatan yang terbaru yaitu SNI 1725:2016 maka para perencana jembatan harus memulai penyesuaian perubahan yang terjadi pada standar tersebut. Tujuan perencanaan ini adalah untuk mengevaluasi pembebanan SNI 1725:2016 dengan pembebanan RSNI T-02-2005 agar memperoleh struktur atas jembatan rangka baja yang aman dan efesien. Perbedaan terbesar dari hasil penerapan SNI 1725:2016 (standar baru) dan RSNI T-02-2005 (standar lama) terletak pada beban angin pada struktur $50 \%$, beban gempa $41 \%$ dan kombinasi pembebanan. Dari hasil analisa kedua pembebanan tersebut dapat disimpulkan pembaharuan standar pembebanan pada SNI 1725:2016 akan memberikan tingkat keamaan yang lebih memadai lagi. (Bima et.al, 2019).

Adapun tujuan dari penelitian ini yaitu mengetahui perhitungan struktur bawah (sub structure) jembatan menggunakan kombinasi pembebanan pada jembatan dengan versi yang baru SNI 1725:2016 sehingga mendapatkan faktor keamanan rencana struktur bawah (sub structure) jembatan.

\section{TINJAUAN PUSTAKA}

Menurut Ir. Agus Iqbal Manu (1995) Secara umum jembatan dapat dibagi menjadi dua bagian yaitu bangunan atas (upper structure) dan bangunan bawah (sub structure).

\section{Bangunan Atas (Upper Structure)}

Struktur atas adalah bagian atas jembatan yang menumpu bagiannya sendiri dan menampung beban yang ditimbulkan dari lalu lintas orang, kendaraan, dan yang lainnya, kemudian menyalurkan ke struktur bawah. Bagian-bagian utama dari struktur atas jembatan antara lain adalah balok utama longitudinal atau stringer atau girder, plat lantai, dan pengaku (bracing atau stiffner), sedangkan bagian sekunder dari struktur atas antara lain adalah parapet, alat sambung dek, dan lain sebagainya. Tiang sandaran, merupakan konstruksi dari jembatan yang terletak diatas trotoar untuk keamanan kendaraan maupun manusia yang menggunakan jembatan.

\section{Bangunan Bawah (Sub Structure)}

Struktur bawah adalah bagian bawah jembatan yang berfunfsi untuk menerima beban dari struktur atas dan kemudian menyalurkan ke pondasi. Bebanbeban tersebut kemudian disalurkan ke tanah. Bagian-bagian dari struktur bawah jembatan antara lain adalah kepala jembatan (abutment), pilar, dan pondasi untuk kepala jembatan dan juga pilar.

Menurut Setiyarto (2017), Sejak dikeluarkannya standar pembebanan untuk jembatan yang terbaru yaitu SNI 17252016 maka para perencana jembatan harus mulai menyesuaikan perubahan yang terjadi pada standar tersebut. Tulisan ini memaparkan tentang pembaharuan yang terjadi pada SNI 1725 2016, seperti jenis-jenis beban dan kombinasi pembebanan. 
Tabel 1. Pembebanan SNI 1725:2016

\begin{tabular}{|c|c|c|}
\hline No & Pembebanan & Keterangan \\
\hline 1 & Beban Mati & $78,5 \mathrm{kN} / \mathrm{m}^{3}$ \\
\hline 2 & Beban Mati Tambahan & Tebal aspal $50 \mathrm{~cm}$ \\
\hline \multirow{6}{*}{3} & beban lalu lintas & \\
\hline & Beban "T" & $500 \mathrm{kN}$ \\
\hline & Beban "D" & \multirow{4}{*}{$\mathrm{q}=9,0(0,5+15 / \mathrm{L}) \mathrm{kPa}$} \\
\hline & Beban Garis Terpusat & \\
\hline & (BGT) & \\
\hline & Beban Terbagi Rata (BTR) & \\
\hline 4 & Beban Pejalan Kaki & $5 \mathrm{kPa}$ \\
\hline 5 & Gaya Rem & $\begin{array}{c}-25 \% \text { dari berat gandartruck desain } \\
-5 \% \text { dari berat truck } \\
\text { rencana ditambah bebanlajur terbagi rata (BTR) }\end{array}$ \\
\hline 6 & Beban Angin & $\begin{array}{l}\text { Menjelaskan tentang tekanan angin horizontaldiselesaikan dengan } \\
\text { persamaan kecepatan anginrencana, atau persamaan tekanan angin } \\
\text { rencana, sertaangin yang bekerja pada kendaraan. } \\
\text { untuk tekanan anginvertikal digunakan apabilajembatan yang lebih } \\
\text { besar dari } 30\end{array}$ \\
\hline 7 & Beban Gempa & $\begin{array}{c}\text { Perhitungan pengaruh gempa terhadap jembatantermasuk beban } \\
\text { gempa, analisis, peta gempa dan detail struktur mengacu } \\
\text { pada (SNI 2833:2008) }\end{array}$ \\
\hline 8 & Kombinasi Pembebanan & $\begin{array}{c}\text { Kombinasi pembebananberjumlah } 12 \text { kombinasidengan jumlah } \\
\text { kategori beban terdapat sepuluh kategori. }\end{array}$ \\
\hline
\end{tabular}

Sumber: Bima et.al, 2019

\section{METODE}

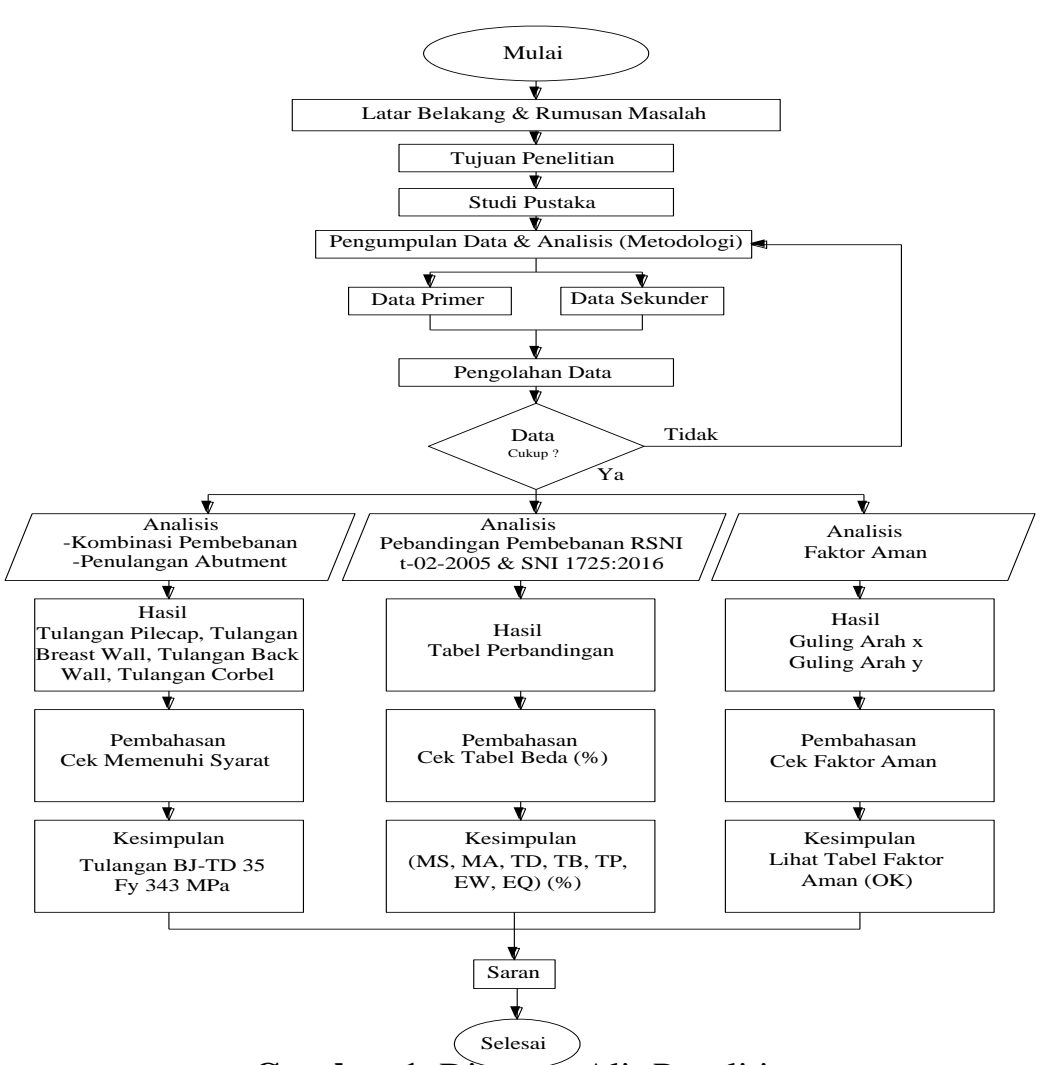

Gambar 1. Díagram Alir Penelitian 


\section{HASIL DAN PEMBAHASAN}

Tabel 2. Kombinasi Pembebanan berdasarkan SNI 1725:2016

\begin{tabular}{|c|c|c|c|c|c|c|c|c|c|c|c|c|}
\hline No & Jenis Beban & $\begin{array}{c}\text { Kuat } \\
\text { I }\end{array}$ & $\begin{array}{c}\text { Kuat } \\
\text { II }\end{array}$ & $\begin{array}{c}\text { Kuat } \\
\text { III }\end{array}$ & $\begin{array}{c}\text { Kuat } \\
\text { IV }\end{array}$ & $\begin{array}{c}\text { Kuat } \\
\text { V }\end{array}$ & $\begin{array}{c}\text { Ekstream } \\
\text { I }\end{array}$ & $\begin{array}{c}\text { Ekstream } \\
\text { II }\end{array}$ & $\begin{array}{c}\text { Daya } \\
\text { Layan } \\
\text { I }\end{array}$ & $\begin{array}{c}\text { Daya } \\
\text { Layan } \\
\text { II }\end{array}$ & $\begin{array}{c}\text { Daya } \\
\text { Layan } \\
\text { III }\end{array}$ & $\begin{array}{c}\text { Daya } \\
\text { Layan } \\
\text { IV }\end{array}$ \\
\hline 1 & Berat Sendri $\left(\mathrm{M}_{\mathrm{s}}\right)$ & $\sqrt{ }$ & $\sqrt{ }$ & $\sqrt{ }$ & $\sqrt{ }$ & $\sqrt{ }$ & $\sqrt{ }$ & $\sqrt{ }$ & $\sqrt{ }$ & $\sqrt{ }$ & $\sqrt{ }$ & $\sqrt{ }$ \\
\hline 2 & $\begin{array}{l}\text { Beban Mati Tambahan } \\
\left(\mathrm{M}_{\mathrm{A}}\right)\end{array}$ & $\sqrt{ }$ & $\sqrt{ }$ & $\sqrt{ }$ & $\sqrt{ }$ & $\sqrt{ }$ & $\sqrt{ }$ & $\sqrt{ }$ & $\sqrt{ }$ & $\sqrt{ }$ & $\sqrt{ }$ & $\sqrt{ }$ \\
\hline 3 & Beban Lajur "D" ( $\left.\mathrm{T}_{\mathrm{D}}\right)$ & $\sqrt{ }$ & $\sqrt{ }$ & & & & $\sqrt{ }$ & $\sqrt{ }$ & $\sqrt{ }$ & $\sqrt{ }$ & $\sqrt{ }$ & \\
\hline 4 & Gaya Rem $\left(\mathrm{T}_{\mathrm{B}}\right)$ & $\sqrt{ }$ & $\sqrt{ }$ & & & & $\sqrt{ }$ & $\sqrt{ }$ & $\sqrt{ }$ & $\sqrt{ }$ & $\sqrt{ }$ & \\
\hline 5 & Beban pejalan kaki $\left(\mathrm{T}_{\mathrm{P}}\right)$ & $\sqrt{ }$ & $\sqrt{ }$ & & & & $\sqrt{ }$ & $\sqrt{ }$ & $\sqrt{ }$ & $\sqrt{ }$ & $\sqrt{ }$ & \\
\hline 6 & Beban angin (Ews) & & & $\sqrt{ }$ & $\sqrt{ }$ & $\sqrt{ }$ & & & $\sqrt{ }$ & & & $\sqrt{ }$ \\
\hline 7 & Beban angin $\left(\mathrm{E}_{\mathrm{WL}}\right)$ & & & & & $\sqrt{ }$ & & & $\sqrt{ }$ & & & \\
\hline 8 & $\begin{array}{l}\text { Pengaruh Temperatur } \\
\left(\mathrm{E}_{\mathrm{T}}\right)\end{array}$ & $\sqrt{ }$ & $\sqrt{ }$ & $\sqrt{ }$ & $\sqrt{ }$ & $\sqrt{ }$ & & & $\sqrt{ }$ & $\sqrt{ }$ & $\sqrt{ }$ & $\sqrt{ }$ \\
\hline 9 & Beban Gempa $\left(E_{Q}\right)$ & & & & & & $\sqrt{ }$ & & & & & \\
\hline
\end{tabular}

Sumber: SNI 1725:2016

Berdasarkan kombinasi pembebanan SNI 1725:2016 mempertimbangkan keadaan batas hingga 11 macam seperti yang dilihat pada Tabel 2, belum termasuk keadaan batas fatik.

Keadaan batas Kuat I dari SNI 17252016 terdiri atas:

- berat sendiri (MS),

- beban mati tambahan (MA),

- beban lajur "D" (TD),

- gaya rem (TB),

- beban pejalan kaki (TP) dan

- pengaruh temperatur.

Dari hasil perhitungan pada tabel 3 kombinasi beban keadaan batas yang digunakan dalam perhitungan selanjutnya hanya yang terbesar dari semua keadaan batas yang ada. Maka kaadaan batas yang digunakan adalah KUAT I. Karena pada keadaan batas kuat satu yang maksimum, maka gaya yang menyebabkan guling.

Untuk arah $\mathrm{x}$,

$\frac{B x}{2}=\frac{2.8}{2}=1.40$

$\mathrm{Mp}=\mathrm{P} \times \mathrm{Bx} \times(1+\mathrm{k})$

Untuk arah $\mathrm{y}$,

$\frac{B x}{2}=\frac{8.00}{2}=4.00$

$\mathrm{Mp}=\mathrm{P} \times \mathrm{Bx} \times(1+\mathrm{k})$

Hasil perhitungan dapat dilihat pada tabel 4 dan tabel 5.
Berasarkan Perhitungan pembebanan SNI yang terbaru ini ditetapkan pada bulan Juni tahun 2016 untuk menggantikan atau merevisi $\begin{array}{llll}\text { pendahulunya yaitu } & \text { SNI } & 03 & 1725\end{array}$ 1989 dengan judul Pembebanan Jembatan Jalan Raya, serta RSNI T-02 2005 berjudul Standar Pembebanan untuk Jembatan. Penyesuaian ketentuan teknis tersebut dapat diikuti dalam peraturan SNI 1725 2016. yang ditetapkan pada bulan Juni tahun 2016, dengan jumlah halaman sebanyak 75 lembar.

Berdasarkan hasil perhitungan perbandingan pembebanan menurut RSNI T-02-2005 dengan SNI 1725:2016.

Diantara perbandingan diatas terdapat pada beban Gaya rem (TB) sebesar 12\%, Beban angin (EW) sebesar 45\%, Beban gempa (EQ) sebesar $51 \%$ sedangakan Berat Sendri (MS), Beban Mati Tambahan (MA), Beban Lajur "D" (TD), Beban pejalan kaki (TP) sebesar 0\%

Hal ini disebabkan oleh:

a. Peninjauan beban angin pada RSNI T-02-2005 tidak mempertimbangkan angin vertical dan angin horizontal seperti halnya pada SNI 1725:2016

b. Beban gempa menurut pada RSNI T-02-2005 menggunakan peta zonasi gempa dengan periode ulang 500 tahun, sedangkan menurut pada SNI 1725:2016 menggunakan peta zonasi gempa dengan periode ulang 1000 
Studi Alternatif Perancangan Substructure .., Eka Purnamasari ${ }^{(1)}$, Revian Daffa Sosiawan ${ }^{(2)}$

tahun.

c. Beban rem menurut menurut pada 1725:2016 mempertimbangkan gaya rem sebesar $5 \%$ dan $25 \%$ dan dicari gaya rem (TB) maksimum RSNI T-02-2005 mempertimbangkan gaya rem sebesar 5\%, sedangkan menurut pada SNI

Tabel 3. Kombinasi Beban dan Faktor Beban Berdasarkan SNI 1725:2016

\begin{tabular}{|c|c|c|c|c|c|c|c|c|c|c|}
\hline Keadaan & $\mathbf{M}_{\mathbf{S}}$ & MA & TA & TD & TB & TP & $\mathbf{E W}_{\mathrm{s}}$ & $\mathbf{E W}_{\mathbf{L}}$ & ET & EQ \\
\hline batas & 223995.0 & 7470 & 50820.37 & 84800.4 & 2450.00 & 6250.00 & 5500.00 & 1825.00 & 1171.88 & 16730.95 \\
\hline \multirow{2}{*}{ Kuat I } & 1.3 & 2 & 1.25 & 1.8 & 1.8 & 1.8 & 0 & 0 & 1.2 & 0 \\
\hline & 291193.50 & 14940.00 & 63525.47 & 152640.77 & 4410.00 & 11250.00 & 0 & 0 & 1406.25 & 0 \\
\hline \multirow{2}{*}{ Kuat II } & 1.3 & 2 & 1.25 & 1.4 & 1.4 & 1.4 & 0 & 0 & 1.2 & 0 \\
\hline & 291193.5 & 14940 & 63525.465 & 118720.6 & 3430 & 8750 & 0 & 0 & 1406.25 & 0 \\
\hline \multirow{2}{*}{ Kuat III } & 1.3 & 2 & 1.25 & 0 & 0 & 0 & 1.4 & 0 & 1.2 & 0 \\
\hline & 291193.5 & 14940 & 63525.465 & 0 & 0 & 0 & 7700 & 0 & 1406.25 & 0 \\
\hline \multirow{2}{*}{ Kuat IV } & 1.3 & 2 & 1.25 & 0 & 0 & 0 & 0 & 0 & 1.2 & 0 \\
\hline & 291193.5 & 14940 & 63525.465 & 0 & 0 & 0 & 0 & 0 & 1406.25 & 0 \\
\hline \multirow{2}{*}{ Kuat V } & 1.3 & 2 & 1.25 & 0 & 0 & 0 & 0.4 & 1 & 1 & 0 \\
\hline & 291193.5 & 14940 & 63525.465 & 0 & 0 & 0 & 2200 & 1825 & 1171.875 & 0 \\
\hline \multirow{2}{*}{ Ektrim I } & 1.3 & 2 & 1.25 & 1 & 1 & 1 & 0 & 0 & 0 & 1 \\
\hline & 291193.5 & 14940 & 63525.465 & 84800.425 & 2450 & 6250 & 0 & 0 & 0 & 16730.95 \\
\hline \multirow{2}{*}{ Ektrim II } & 1.3 & 2 & 1.25 & 0.5 & 0.5 & 0.5 & 0 & 0 & 0 & 0 \\
\hline & 291193.5 & 14940 & 63525.465 & 42400.213 & 1225 & 3125 & 0 & 0 & 0 & 0 \\
\hline \multirow{2}{*}{$\begin{array}{l}\text { Daya } \\
\text { layan I }\end{array}$} & 1 & 1 & 1 & 1 & 1 & 1 & 0.3 & 1 & 1 & 0 \\
\hline & 223995 & 7470 & 50820.372 & 84800.425 & 2450 & 6250 & 1650 & 1825 & 1171.875 & 0 \\
\hline \multirow{2}{*}{$\begin{array}{c}\text { Daya } \\
\text { layan II }\end{array}$} & 1 & 1 & 1 & 1.3 & 1.3 & 1.3 & 0 & 0 & 1 & 0 \\
\hline & 223995 & 7470 & 50820.372 & 110240.55 & 3185 & 8125 & 0 & 0 & 1171.875 & 0 \\
\hline \multirow{2}{*}{$\begin{array}{c}\text { Daya } \\
\text { layan III }\end{array}$} & 1 & 1 & 1 & 0.8 & 0.8 & 0.8 & 0 & 0 & 1 & 0 \\
\hline & 223995 & 7470 & 50820.372 & 67840.34 & 1960 & 5000 & 0 & 0 & 1171.875 & 0 \\
\hline \multirow{2}{*}{$\begin{array}{c}\text { Daya } \\
\text { layan IV }\end{array}$} & 1 & 1 & 1 & 0 & 0 & 0 & 0.7 & 0 & 1 & 0 \\
\hline & 223995 & 7470 & 50820.372 & 0 & 0 & 0 & 3850 & 0 & 1171.875 & 0 \\
\hline \multirow{2}{*}{$\begin{array}{l}\text { Fatik } \\
\text { (TD dan }\end{array}$} & 0 & 0 & 0 & 0.75 & 0.75 & 0.75 & 0 & 0 & 0 & 0 \\
\hline & 0 & 0 & 0 & 63600.319 & 1837.5 & 4687.5 & 0 & 0 & 0 & 0 \\
\hline
\end{tabular}

Tabel 4. Stabilitas Guling Abutment Arah X

\begin{tabular}{cccccccccc}
\hline $\begin{array}{c}\text { Kombinasi } \\
\text { Beban }\end{array}$ & $\begin{array}{c}\text { Tegangan } \\
\text { Berlebihan }\end{array}$ & $\begin{array}{c}\mathrm{P} \\
\mathrm{kN}\end{array}$ & $\begin{array}{c}\mathrm{Mx} \\
\mathrm{kN} . \mathrm{m}\end{array}$ & $\begin{array}{c}\text { My } \\
\mathrm{kN} . \mathrm{m}\end{array}$ & $\begin{array}{c}\mathrm{Mpx} \\
\mathrm{kN} . \mathrm{m}\end{array}$ & $\mathrm{SF}$ & $>\begin{array}{c}\text { Angka } \\
\text { aman }\end{array}$ & Ket. \\
\hline KUAT I & $0 \%$ & 329.99 & 102.55 & 8.70 & 461.98 & 4.50502 & $>$ & 2.2 & OK \\
KUAT II & $25 \%$ & 263.99 & 82.04 & 6.96 & 461.98 & 5.63127 & $>$ & 2.2 & OK \\
KUAT III & $25 \%$ & 186.84 & 59.65 & 27.20 & 326.97 & 5.48182 & $>$ & 2.2 & OK \\
KUAT IV & $40 \%$ & 165.33 & 53.26 & 6.22 & 324.05 & 6.0848 & $>$ & 2.2 & OK \\
KUAT V & $40 \%$ & 166.82 & 57.30 & 24.29 & 326.97 & 5.70661 & $>$ & 2.2 & OK \\
EKTREM I & $50 \%$ & 215.01 & 92.75 & 13.61 & 451.52 & 4.86821 & $>$ & 2.2 & OK \\
\hline
\end{tabular}


Studi Alternatif Perancangan Substructure .., Eka Purnamasari ${ }^{(1)}$, Revian Daffa Sosiawan ${ }^{(2)}$

Tabel 5. Stabilitas Guling Abutment Arah Y

\begin{tabular}{cccccccccc}
\hline $\begin{array}{c}\text { Kombinasi } \\
\text { Beban }\end{array}$ & $\begin{array}{c}\text { Tegangan } \\
\text { Berlebihan }\end{array}$ & $\begin{array}{c}\mathrm{P} \\
\mathrm{kN}\end{array}$ & $\begin{array}{c}\mathrm{Mx} \\
\mathrm{kN} . \mathrm{m}\end{array}$ & $\begin{array}{c}\text { My } \\
\mathrm{kN} . \mathrm{m}\end{array}$ & $\begin{array}{c}\mathrm{Mpx} \\
\mathrm{kN} . \mathrm{m}\end{array}$ & $\mathrm{SF}$ & $>\begin{array}{c}\text { Angka } \\
\text { aman }\end{array}$ & Ket. \\
\hline KUAT I & $0 \%$ & 329.99 & 102.55 & 8.70 & $1,319.94$ & 12.8715 & $>$ & 2.2 & OK \\
KUAT II & $25 \%$ & 263.99 & 82.04 & 6.96 & $1,319.94$ & 16.0894 & $>$ & 2.2 & OK \\
KUAT III & $25 \%$ & 186.84 & 59.65 & 27.20 & 934.20 & 15.6623 & $>$ & 2.2 & OK \\
KUAT IV & $40 \%$ & 165.33 & 53.26 & 6.22 & 925.86 & 17.3852 & $>$ & 2.2 & OK \\
KUAT V & $40 \%$ & 166.82 & 57.30 & 24.29 & 934.20 & 16.3046 & $>$ & 2.2 & OK \\
EKTREM I & $50 \%$ & 215.01 & 92.75 & 13.61 & $1,290.06$ & 13.9092 & $>$ & 2.2 & OK \\
\hline
\end{tabular}

Tabel 6. Rekapitulasi Kombinasi Beban Nominal Pada Keadaan Ultimit.

\begin{tabular}{ccccccc}
\hline No. & Beban & $\begin{array}{c}\mathrm{P} \\
\text { (ton) }\end{array}$ & $\begin{array}{c}\text { Tx } \\
\text { (ton) }\end{array}$ & $\begin{array}{c}\text { Ty } \\
\text { (ton) }\end{array}$ & $\begin{array}{c}\text { Mx } \\
\text { (t.m) }\end{array}$ & $\begin{array}{c}\text { My } \\
\text { (t.m) }\end{array}$ \\
\hline 1 & Kombinasi 1 & 362.69 & 71.57 & - & - & 89.00 \\
2 & Kombinasi 2 & 306.10 & 54.32 & - & - & 66.61 \\
3 & Kombinasi 3 & 294.85 & 54.32 & - & - & 66.61 \\
4 & Kombinasi 4 & 294.85 & 54.32 & - & - & 66.61 \\
5 & Kombinasi 5 & 294.85 & 77.73 & 34.39 & - & 50.63 \\
6 & Kombinasi 6 & 210.05 & 32.74 & - & - & 38.62 \\
\hline
\end{tabular}

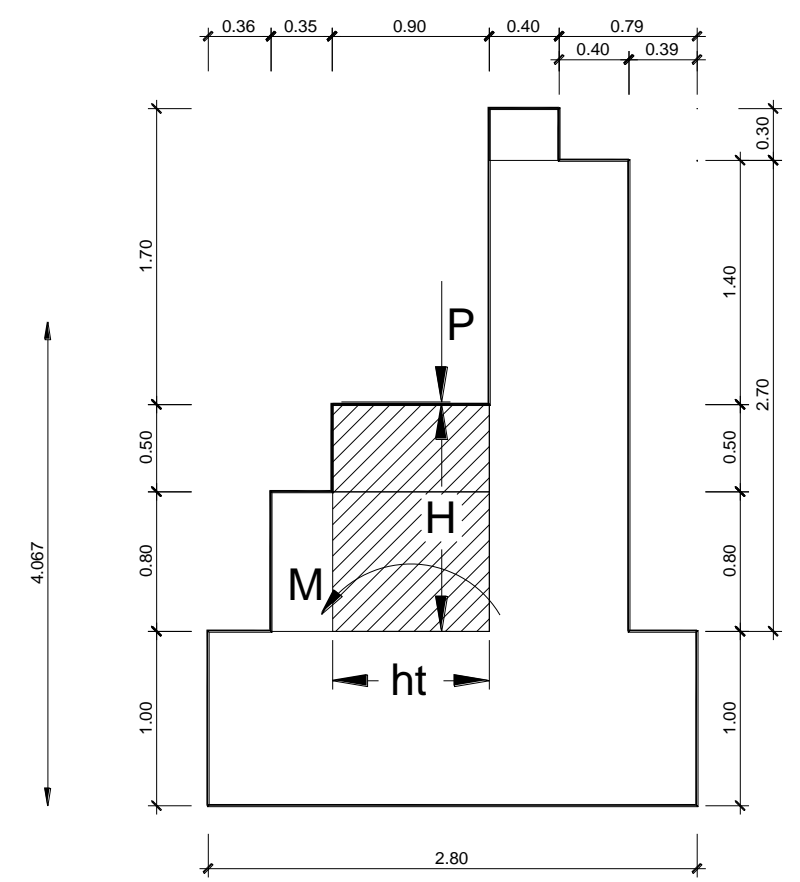

Gambar 2. Beban Kerja pada Breast Wall.

Karena bidang yang menopang beban aksial pada Breast Wall tiga kali lebih pendek dari sisi yang tidak menopang ( 3.ht $<\mathrm{H}$ ), sehingga Breast Wall diasumsikan sebagai kolom. Beban P paling besar berada pada kombinasi 1, jadi sebagai beban acuan diambil dari kombinasi 1 . 
Studi Alternatif Perancangan Substructure .., Eka Purnamasari ${ }^{(1)}$, Revian Daffa Sosiawan ${ }^{(2)}$

\section{Tulangan lentur Breast Wall}

$\mathrm{P}=362,69$ ton

$\mathrm{M}=89,00 \mathrm{t} . \mathrm{m}$

By $=8,00 \mathrm{~m}$

$\mathrm{Pu}=\frac{P}{B y}=\frac{362,69}{8,00}$

$$
\begin{aligned}
& =45,34 \text { ton } \\
\mathrm{Mu}=\frac{M}{B y} & =\frac{89,00}{8,00} \\
& =11,15 \mathrm{t} . \mathrm{m} \\
\mathrm{ht} \quad & =900 \mathrm{~mm}
\end{aligned}
$$

d' = selimut beton, berdasarkan RSNI

T-12-2004, pasal 4.6.3

$=45 \mathrm{~mm}$

$\mathrm{d} \quad=h t-\left(2 x d^{\prime}\right)=900-(2 \times 45)$

$=810 \mathrm{~mm}$

$\mathrm{b}=1000$ (lebar tinjauan, per $1 \mathrm{~m}$ )

$\mathrm{f}^{\prime} \mathrm{c}=25 \mathrm{MPa}$

fy $=343 \mathrm{Mpa}$

$\beta=$ Mengacu SNI 03-2847-2002

$\mathrm{f}^{\prime} \mathrm{c} \leq 25 \mathrm{MPa} \rightarrow \beta=0,85$

$\mathrm{f}^{\prime} \mathrm{c} \geq 25 \mathrm{MPa} \rightarrow \beta=0,85-0,0008\left(\mathrm{f}^{\prime} \mathrm{c}-\right.$ )

$\{$ tetapi jika hasil $\beta<0,65$ maka $\beta=0,65$ \}

$=0,85-0,0008(25-300)$

$=1,070$

$\varphi \quad=0,65$ (faktor reduksi SNI 03-2847-2002)

$\mathrm{Mn}=\frac{M u}{\varphi}=\frac{11,15 \times 10^{7}}{0,65}$

$=171.156 .295,27 \mathrm{~N} \cdot \mathrm{mm}$

Pn $\quad=\frac{P_{u}}{\varphi}=\frac{45,34 \times 10^{4}}{0,65}$

$=697.488,20 \mathrm{~N}$

$\mathrm{e} \quad=\frac{M n}{P_{n}}=\frac{171.156 .295,27}{697.488,20}$

$=245,39 \mathrm{~mm}$

$\rho \quad=$ syarat $(1 \%<\rho<8 \%)$

$=$ Diambil $1 \%$

$\mathrm{As}_{\text {perlu }}=\rho x b x d$

$=0,01 \times 900 \times 860$

$$
=8100 \mathrm{~mm}^{2}
$$

$\mathrm{As}_{\mathrm{tarik}}=\mathrm{As}_{\text {tarik }}=\mathrm{As}_{\mathrm{tekan}}$

$=\frac{\text { Asperlu }}{3}=\frac{8100}{3}$

$=2.700 \mathrm{~mm}^{2}$

$\mathrm{D} \quad=25 \mathrm{~mm}$

Astul. $\quad=\frac{1}{4} \cdot \pi \cdot\left(D^{2}\right)=\frac{1}{4} \cdot 3,14 \cdot\left(25^{2}\right)$

$=490,63 \mathrm{~mm}^{2}$

$\mathrm{s} \quad=$ Jarak antar tulangan

$=\frac{\text { Atul. } x b}{\text { Astarik }}=\frac{490,63 x 900}{2700}$

$=181,71 \approx 150 \mathrm{~mm}$

As $\quad=\frac{\text { Atul. } x b}{s}=\frac{490,63 x 900}{150}$

$$
=3.270,83 \mathrm{~mm}^{2}
$$

Cek, As $>\mathrm{As}_{\text {Tarik }} \rightarrow 3.270,83>2.700,00 \ldots \ldots$. OK

\section{Kontrol baja tulangan Breast Wall}

$$
\begin{aligned}
\mathrm{cb} & =\frac{600 x d}{600+f y} \\
& =\frac{600 x 810}{600+343} \\
& =515,38 \mathrm{~mm} \\
\mathrm{ab} \quad & =\beta x \mathrm{cb} \\
& =1,062 \times 515,38 \\
& =551,45 \mathrm{~mm} \\
\mathrm{fs} & =\text { tegangan tulangan baja tekan } \\
& =600 \cdot\left[\frac{c b-\left(d^{t} \times 2\right)}{c b}\right] \\
& =600 \cdot\left[\frac{515,38-(45 \times 2)}{515,38}\right] \\
& =495,22 \mathrm{MPa}
\end{aligned}
$$

Cek, fs' $\leq$ fy

495,22 $\leq 343 \mathrm{MPa}$........Tidak memenuhi syarat, maka

$$
\begin{aligned}
\text { fs' } & =f y=343 \mathrm{MPa} \\
\text { As' } & =\frac{M n}{(d-(d v x 2)) \cdot f y} \\
& =\frac{171.156 .295,27}{(810-(45 x 2)) \cdot 343} \\
& =693,05 \mathrm{~mm}^{2} \\
\mathrm{fs} & =\text { tegangan tulangan baja Tarik } \\
& =600 \cdot\left[\frac{d-c b}{c b}\right] \\
& =600 \cdot\left[\frac{810-515,38}{515,38}\right] \\
& =343 \leq \mathrm{fy}=343 \\
\mathrm{Pn}_{\mathrm{b}} & =10.834 .193,46 \mathrm{~N} \\
\mathrm{Mn}_{\mathrm{b}} & =1.723 .898 .500,27 \mathrm{~N} . \mathrm{mm} \\
\mathrm{e}_{\mathrm{b}} & =\frac{M n b}{P_{n b}} \\
& =\frac{1.723 .898 .500,27}{10.834 .193,46} \\
& =159,12 \mathrm{~mm}
\end{aligned}
$$

Cek jenis keruntuhan yang terjadi :

$\mathrm{Pn}_{\mathrm{b}}>\mathrm{Pn}=10.834 .193,46>697.488,20 \mathrm{~N}$

$\mathrm{e}_{\mathrm{b}}<\mathrm{e} \quad=159,12<245,39 \mathrm{~mm}$

Maka terjadi keruntuhan tarik.

Analisa kolom jika terjadi keruntuhan tarik :

$$
\begin{aligned}
\alpha & =\frac{A s}{b x d}=\frac{3270,83}{900 x 810} \\
& =0,004 \\
\mathrm{~m} \quad & =\frac{f y}{0,85 x f^{\prime} C}=\frac{343}{0,85 \times 25} \\
& =16,14 \\
\mathrm{Pn}_{\text {tarik }} & =-4.347 .982,86 \rightarrow 4.347 .982,86 \mathrm{~N} \\
\mathrm{Mn}_{\text {tarik }} & =\mathrm{Pn}_{\text {tarik }} \mathrm{X} \mathrm{e} \\
& =4.347 .982,86 \times 245,39 \\
& =1.066 .949 .428,67 \mathrm{~N} . \mathrm{mm}
\end{aligned}
$$


Studi Alternatif Perancangan Substructure .., Eka Purnamasari ${ }^{(1)}$, Revian Daffa Sosiawan ${ }^{(2)}$

Cek baja tulangan :

$\mathrm{Pn}_{\text {tarik }}>\mathrm{Pn} \rightarrow 5.377 .027,72>697.488,20$ N....OK

$\mathrm{Mn}_{\text {tarik }}>\mathrm{Mn} \rightarrow 1.059 .080 .851,18>$

$171.156 .295,27$ N.mm.......OK

Jadi baja tulangan digunakan $=\mathrm{D} 25-150 \mathrm{~mm}$.

Tulangan bagi Breast Wall :

$\mathrm{As}_{\text {perlu }}=$ Diambil $30 \%$ dari tulangan pokok daerah tarik

$=\rho \times b \times d \times 30 \%$

$=2.700 \times 30 \%$

$=810 \mathrm{~mm}^{2}$

$\mathrm{D} \quad=16 \mathrm{~mm}$

$\mathrm{A}_{\text {tul. }}=\frac{1}{4} \cdot \pi \cdot\left(D^{2}\right)$

$=\frac{1}{4} \cdot 3,14 \cdot\left(16^{2}\right)$

$=200,96 \mathrm{~mm}^{2}$

$\mathrm{s} \quad=$ Jarak antar tulangan

$=\frac{\text { Atul. } x b}{\text { Asperlu }}=\frac{200,96 \times 900}{810}$

$=248,10 \mathrm{~mm} \approx 150 \mathrm{~mm}$

As $\quad=\frac{\text { Atul. } x b}{s}=\frac{200,96 \times 900}{150}$

$=1339,73 \mathrm{~mm}^{2}$

Cek dengan syarat, As $>\mathrm{As}_{\text {perlu }}$

$\rightarrow 1.339,73>810 \ldots \ldots$. OK

Digunakan tulangan $=\mathrm{D} 16-150 \mathrm{~mm}$.

\section{Tulangan geser Breast Wall :}

$\mathrm{Pu}=453.367,33 \mathrm{~N}$

$\mathrm{Mu}=111.251 .591,93$ N.mm

$\mathrm{H}=$ tinggi efektif breast wall

$=1100 \mathrm{~mm}$

d' $=45 \mathrm{~mm}$

ht $\quad=900 \mathrm{~mm}$

$\mathrm{d} \quad=810 \mathrm{~mm}$

$\mathrm{A}_{\text {lentur }}=$ luas tulangan pokok

$=3.271 \mathrm{~mm}^{2}$

As = luas tulangan total, dimana ada $2 \operatorname{sisi}\left(\mathrm{A}_{\text {tarik }}\right.$

dan $\mathrm{A}_{\text {tekan }}$ )

$=3271 \times 2$

$=6.542 \mathrm{~mm}^{2}$

$\mathrm{Vu}=\frac{M u}{H}=\frac{111.251 .591,93}{1.100}$

$=101.137,81 \mathrm{~N}$

$\mathrm{Ve}_{\text {maks }}=0,2 x f^{\prime} c x b x d$

$=0,2 \times 25 \times 900 \times 810$

$=4.050 .000 \mathrm{~N}$

$\varphi \mathrm{Ve}_{\text {maks }}=0,75 \times 4.050 .000$

$=3.0375 .500 \mathrm{~N}$

$\beta 1=1,4-\frac{d}{2000}=1,4-\frac{860}{2000}$

$=0,995$

$$
\begin{aligned}
\beta 2 & =1+\frac{P_{u}}{14 x f^{\prime} c x b x h t} \\
& =1+\frac{547.661,37}{14 \times 25 \times 900 \times 1000} \\
& =1 \\
\beta 3 & =1 \\
\text { Vuc } & =\beta 1 \times \beta 2 \times \beta 3 \times \mathrm{b} \times \mathrm{d} \times \sqrt{\frac{\text { Asx f } f^{\prime} C}{b x d}}
\end{aligned}
$$

$=$

$0,995 \times 1 \times 1 \times 900 \times 810 \times \sqrt{\frac{6.542 \times 25}{1000 \times 810}}$

$=362.663,97 \mathrm{~N}$

$\mathrm{Vc}=V u c+0,6 \times b \times d$

$=V u c+0,6 \times 900 \times 810$

$=848.663,97 \mathrm{~N}$

$\varphi \mathrm{Vc}=0,75 \times 848.663,97$

$=636.497,98 \mathrm{~N}$

Cek, $\varphi \mathrm{Vc}>\mathrm{Vu}$ $636.497,98>81.179,13$ N.......OK

(Hanya Perlu Tulangan Minimum, D10)

$\mathrm{Vs} \quad=\mathrm{Vu}=101.137,81 \mathrm{~N}$

fy $=343 \mathrm{MPa}$

$\mathrm{D} \quad=10 \mathrm{~mm}$

$\mathrm{A}_{\text {tul. }}=\frac{1}{4} \cdot \pi \cdot\left(D^{2}\right)$

$=\frac{1}{4} \cdot 3,14 \cdot\left(10^{2}\right)$

$=78,5 \mathrm{~mm}^{2}$

$\mathrm{S}_{\text {bagi }}=$ jarak tulangan bagi

$=150 \mathrm{~mm}$

Asv $=$ Atul. $x \frac{b}{\text { sbagi }}$

$=$ Atul $\cdot x \frac{1000}{150}$

$=523 \mathrm{~mm}^{2}$

Berdasarkan RSNI T-12-2004 untuk jarak maksimum antar tulangan diambil yang terkecil antara :

$\mathrm{s} 1=3 \times$ Asv $x \frac{f y}{b}$

$=3 \times 523 \times \frac{343}{1000}$

$=538,51 \mathrm{~mm} \rightarrow 500 \mathrm{~mm}$

$\mathrm{s} 2=1,35 \cdot \mathrm{ht}=1,35 \times 1000$

$=1.350 \mathrm{~mm}$

$\mathrm{s} 3=300 \mathrm{~mm}$

Jadi, $\mathrm{s}=300 \mathrm{~mm}$

Tulangan yang dipakai :

D10-300 $\mathrm{mm} \rightarrow$ pemasangan searah memanjang abutment.

D10 $-150 \mathrm{~mm} \rightarrow$ pemasangan searah vertikal abutment. 
Sketsa penulangan Breast Wall dapat dilihat pada gambar 2 yaitu Sketsa penulangan dikhususkan

untuk Breast Wall.

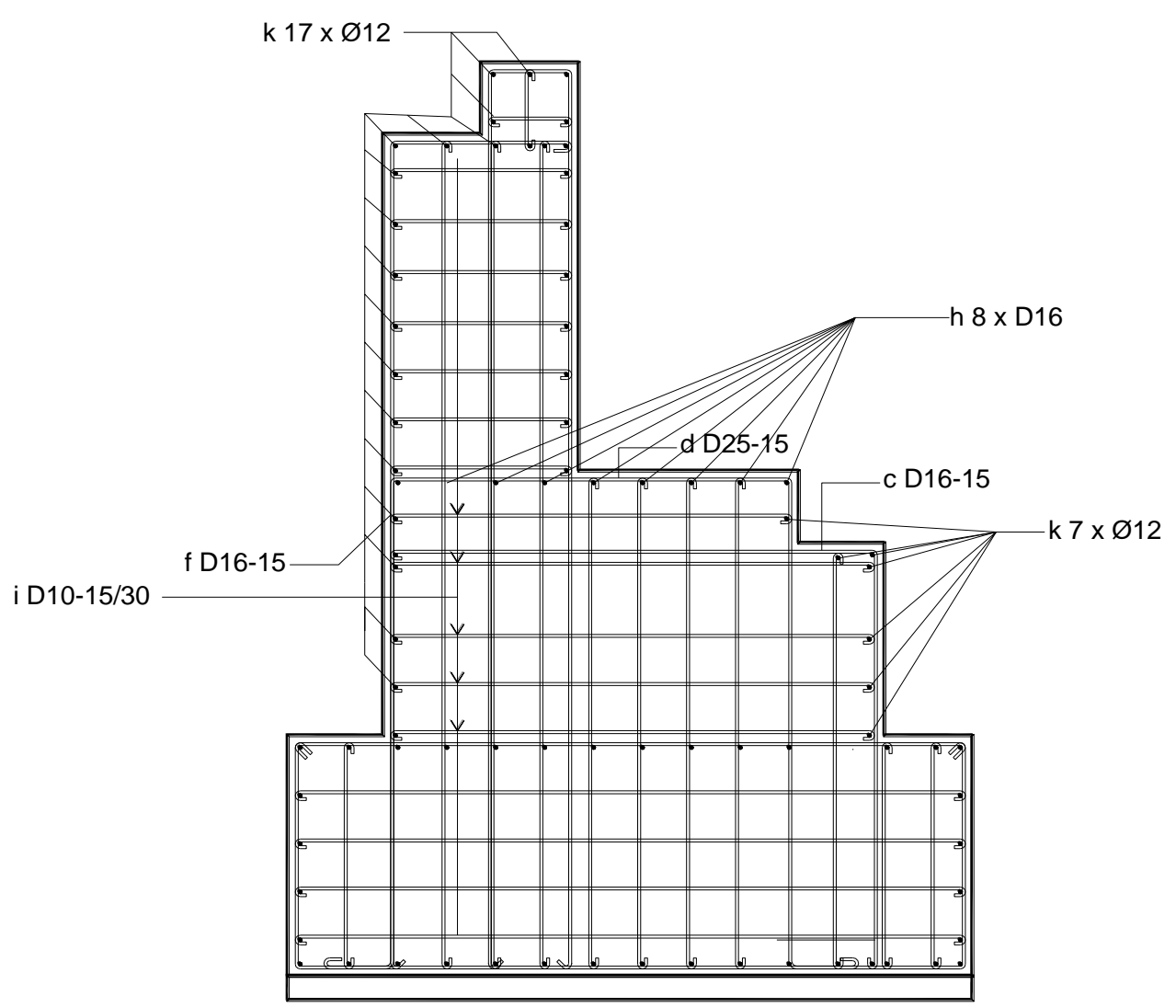

Gambar 3. Sketsa Penulangan Breast Wall .

\section{KESIMPULAN}

Bedasarkan hasil perhitungan Substructure Abutment jembatan Desa Kuala Tambangan memiliki panjang sebesar $8,00 \mathrm{~m}$, dan lebar sebesar $2,80 \mathrm{~m}$. Mutu beton yang digunakan yaitu $25 \mathrm{MPa}$ dan mutu baja tulangan yaitu BJ-TD 35 dengan mutu baja $343 \mathrm{MPa}$. Hasil perhitungan faktor keamanan pada guling abutment jembatan yaitu arah x pada Kuat I, Kuat II, Kuat III, Kuat IV, Kuat V, dan Ektrem I memiliki nilai keamanan >2,2. Sedangkan faktor keamanan pada guling abutment jembatan yaitu arah y pada Kuat I, Kuat II, Kuat III, Kuat IV, Kuat V, dan Ektrem I memiliki nilai keamanan $>2,2$.

\section{DAFTAR PUSTAKA}

Bima, S., Iskandar, I., \& Pahlawan, T. (2019). Evaluasi Perencanaan Struktur Atas Jembatan Rangka Baja Berdasarkan Pembebanan RSNI
T-02-2005 dan SNI 1725: 2016. Jurnal Sipil Sains Terapan, 1(03).2019

Badan Standarisasi Nasional. (2005). Standar Pembebanan Jembatan, Jakarta

Badan Standarisasi Nasional. (2004). Perencanaan Struktur Beton untuk Jembatan, RSNI - T - 12 2004. Jakarta

Badan Standarisasi Nasional. (2016). Standar Pembebanan Jembatan, SNI 1725 : 2016. Jakarta

Badan Standarisasi Nasional. (2008). Perencanaan jembatan terhadap beban gempa, SNI 2833 : 2008. Jakarta

CV. ANS CONSULINDO, (2017). Laporan Penyelidikan Tanah Proyek Pembangunan Jembatan Ruas Batakan - Kuala Tambangan

Manu, Agus Iqbal. (1995). Dasar-Dasar Perencanaan Jembatan Beton Bertulang. PT Mediatama Saptakarya, DPU.

Setiyarto, Y. D. (2017). Standar Pembebanan Pada Jembatan Menurut SNI 17252016. 